\title{
МОДЕЛЬ ПРОФЕСІЙНОЇ КОМПЕТЕНТНОСТІ МАЙБУТНЬОГО ВЧИТЕЛЯ МУЗИЧНОГО МИСТЕЦТВА
}

\author{
(C) Желанова В.В., 2020 \\ https://orcid.org/0000-0001-9467-1080 \\ http://doi.org/10.34142/2312-2471.2020.63.06
}

\begin{abstract}
Актуальність поданої статті зумовлена соціально-економічними, інноваційно-освітніми трансформаціями в житті України, а також глобалізаційними процесами, зорієнтованими на інтеграцію намої держави із світовою спільнотою. У изому сенсі викликає науковий і практичний інтерес проблема професійноӥ компетентності майбутнього вчителя музичного мистецтва, діяльність якого зорієнтована на формування духовності, естетизму, моральної та ціннісної сфер особистості. Метою статті $\epsilon$ обгрунтування й розробка моделі професійної компетентності майбутнього вчителя музичного мистецтва. Використано комплекс методів дослідження, $а$ саме: аналіз, синтез, порівняння, узагальнення, моделювання для вивчення, зіставлення й узагальнення наукових джерел з метою визначення сутності та структури професійної компетентності майбутнього вчителя музичного мистецттва та розробки ї моделі. Визначено сутність компетентнісного підходу як пріоритетної стратегї в мистецьькій освіті та розкрито його базові поняття: компетенція, компетентність, професійна компетентність. Представлено авторську дефініцію професійної компетентності майбутнього вчителя музичного мистецтвва. Проаналізовано базові позиціі теоріі моделювання. Висвітлено більи грунтовні підходи до структури професійної компетентності вчителя музичного мистецтвва, щ̧о подані в студіях дослідників мистецьької освіти. На засаді структурно-діяльнісної ознаки та типів компетентностей вчителів музичного мистецтва, пов'язаних з видами їх професійної діяльності (музично-педагогіної, диригентсько-хорової, музичновиконавської), обгрунтовано й розроблено модель професійної компетентності майбутнього вчителя музичного мистецттва, щ̧о містить мотиваційноиіннісний, когнітивний, креативно-діяльнісний компоненти. Доведено, щуо подана модель відбиває структурні компоненти професійної компетентності майбутнього вчителя музичного мистецтва $i$ за свосю сутністю $\epsilon$ концептуальною, прогностичною, структурно-компонентною.
\end{abstract}

Ключові слова: компетентнісний підхі, структура професійної компетентності, майбутній вчитель музичного мистецтвва. 
Zhelanova V.V. Model of Professional Competency for a Future Teacher of Music Art

The relevance of this article is conditioned by socio-economic, innovative and educational transformations in Ukraine's life, as well as by globalization processes focused on our state's integration with the world community. In this sense, scientific and practical interest is risen by the problem of professional competency of a future teacher of music art, whose activities are focused on the formation of spirituality, aesthetics, moral and value spheres of a personality. The purpose of the article is to substantiate and develop a model of professional competency for a future teacher of music art. A complex of research methods has been used, namely: analysis, synthesis, comparison, generalization, modeling for the study, comparison and generalization of scientific sources in order to determine the essence and structure of professional competency for a future teacher of music art and to develop its model. The essence of a competence-based approach as a priority strategy in art education has been determined and its basic concepts have been revealed: competence, competency, professional competency. The author's definition of professional competency for a future teacher of music art has been presented. The basic positions of the theory of modeling have been analyzed. More fundamental approaches to the structure of professional competency of a teacher of music have been highlighted that are presented in the studies of art education researchers. Based on the principle of structural and activity characteristics and types of teachers' competencies of musical art related to the types of their professional activities (musical and pedagogical, conductor and choral, musical and performing), the model of professional competency for a future teacher of musical art, containing motivational-value, cognitive, creative and activity components, has been substantiated and developed. It has been proved that the presented model reflects the structural components of professional competency for a future teacher of music art and is inherently conceptual, prognostic, structural and componential.

Key words: competence-based approach, professional competency, structure of professional competency, future teacher of music art.

Постановка проблеми. Модернізаційні процеси, що пронизують всі ланки сучасної освіти й пов'язані зі стрімкими соціально-економічними, інноваційно-освітніми трансформаціями в житті України, а також 3 глобалізаційними процесами, зорієнтованими на інтеграцію нашої держави із світовою спільнотою, об'єктивно зумовлюють потребу сучасного суспільства в компетентних, конкурентноспроможних фахівцях, зокрема, у вчителях музичного мистецтва.

Актуальність й необхідність дослідження феномену професійної компетентності майбутніх вчителів музики посилюється й тим, що саме вчителі цієї освітньої галузі стоять у витоків формування духовної, ціннісної та емоційної сфер особистості. При цьому процес формування професійної компетентності майбутнього вчителя музичного мистецтва має грунтуватися на 
певних прогностичних орієнтирах. Таким результативно-цільовим орієнтиром, на нашу думку, може стати модель професійної компетентності майбутнього вчителя музичного мистецтва.

Аналіз останніх досліджень і публікацій дозволив констатувати, що глибокому вивченню фундаментальних засад компетентнісного підходу присвячено студії О. Субетто, І. Байденко, І. Зимньої, Ю. Татура та. Компетентнісний підхід у системі освіти став предметом наукового дослідження Н. Бібік, С. Вітвицької, О. Дубасенюк, О. Локшиної, О. Овчарук, О. Пометун, О. Савченко та ін.

Феномен „професійної компетентності” досліджено у працях С.Гончаренко, В. Журавльова, I. Зязюна, В. Калініна, Л. Карпової, I. Колеснікової, В. Сластьоніна. Професійна компетентність вчителя музичного мистецтва розробляється А. Козир, Л. Масол, М. Михаськовою, О. Олексюк, Т. Пляченко, А. Растригіною, Р. Савченко, О. Щолоковою та іншими мистецтвознавцями. Різні аспекти теорії та практики моделювання розкрито в працях М. Амосова, В. Ахутина, А. Братко, В. Глушкова, М. Кларіна, В. Штоффа та ін.

Виділення невирішених раніше частин загальної проблеми. Проте недостатньої дослідженим $\epsilon$ обгрунтування й розробка моделі професійної компетентності майбутнього вчителя музичного мистецтва.

Формулювання цілей статті. Метою статті $є$ обгрунтування й розробка моделі професійної компетентності майбутнього вчителя музичного мистецтва; завданнями - проаналізувати грунтовні положення теорії моделювання, висвітлити сучасні підходи до трактування сутності й структури професійної компетентності майбутнього вчителя музичного мистецтва.

Методи дослідження. У поданому дослідженні використано комплекс методів дослідження, а саме: аналіз, синтез, порівняння, узагальнення, моделювання для вивчення, зіставлення й узагальнення наукових джерел 3 метою визначення сутності та структури професійної компетентності майбутнього вчителя музичного мистецтва та розробки їі моделі.

Виклад основного матеріалу. Концептульною основою компетентнісно зорієнтованої освіти є впровадження компететнісного підходу, що є спрямованістю освіти на розвиток особистості в результаті формування в неї таких особистісних якостей, як компетентність засобами розв'язання професійних i соціальних завдань у освіті (І. Зимня)[2]; на формування й розвиток ключових (базових, основних) та предметних компетентностей особистості (О. Пометун) [6]. Грунтовними поняттями компетентнісного підходу є категорії „компетенція” та „компетентність”, які трактуємо таким чином:

- компетенція - це задана вимога, норма освітньої підготовки; це об'єктивна сукупність певних знань у будь-якій галузі; це змістовна, потенційна характеристика; коло повноважень якої-небудь організації, установи або особистості; 
- компетентність є суб'єктивною, актуальною, особистісною характеристикою; це реально сформовані особистісні якості та досвід діяльності особистості.

У форматі представленого дослідженні використовується поняття професійна компетентність. Щодо професійної компетентності фахівців музичного мистецтва відома думка, суголосно якої вона розглядається як «інтегративна особистісна якість, що виражає здатність до самостійної успішної реалізації завдань музичної освіти дітей на основі «системного зв'язку загальногромадянських, психолого-педагогічних та музично-фахових компетенцій» [7, с. 13].

Також вона трактується як «системна, інтегрована якість, як здатність усвідомлювати художньо-образний зміст музичних творів у контексті навколишньої дійсності, засвоювати й розуміти основні закономірності, жанрово-стильові особливості, володіти засобами художньо-виконавського втілення» [1, с. 10]. На нашу думку, професійна компетентність вчителя музики - це характеристика фахівця, яка об'єднує його основні професійноособистісні якості, а також готовність реалізувати їх у ситуаціях професійної діяльності.

Отже, подане визначення професійної компетентності вчителя музичного мистецтва синтезує структурну (професійно-особистісні якості) й динамічну (готовність до їх реалізації) її складові. $€$ логічним, що процес моделювання має також ураховувати ці аспекти професійної компетентності.

Зазначимо, що у процесі моделювання ми базувалися на усталених позиціях теорії моделювання. Поняття «модель» походить (від фр. modele і лат. modulus - міра, зразок, норма) й означає «зразок, зразковий екземпляр якого-небудь виробу, або відтворений, зазвичай у зменшеному вигляді, зразок якої-небудь споруди» [4, с. 361].

Відомі визначення моделі як ізоморфного аналогу реального прототипу (А. Братко, П. Волков, А. Кочергін) [3]; як «системи, що подумки уявляється або матеріально реалізується й, відбиваючи, й відтворюючи об'єкт дослідження, здатна замінити його так, що іiі вивчення дає нам нову інформацію про цей об'єкт» (В. Штофф) [10, с. 28]. Більш повним є поняття моделі як зразка схеми, форм i формул тощо [2]. Відзначимо, що саме це трактування моделі $\epsilon$ узасаднювальним для нас.

Отже, $є$ очевидним, що всі вони так чи так стосуються таких якостей моделей, як: відповідність, подібність системі-оригіналу, цілеспрямованість, відволікання, абстрагування від деяких деталей і параметрів системи-оригіналу, репрезентація, екстраполяція. У представлених визначеннях поняття „модель” фіксуються іiі певні характеристики, а саме: 1) іiі співвіднесеність; 2) схематичність; 3) зручність; 4) «людяність»; 5) ідеальність дій.

Надамо характеристику моделі професійної компетентності майбутнього вчителя музичного мистецтва . 
1. Вона створена на підставі теоретичного осмислення особливостей професійної діяльності вчителя музичного мистецтва, тож вона $є$ конщептуальною.

2. Вона співвідноситься з результативною метою професійної підготовки майбутніх вчителів майбутнього мистецтва і є прогностичною.

3. Вона є структурно-компонентною, оскільки відбиває структурну будову професійної компетентності професійної компетентності вчителя музичного мистецтва.

Відтак, процес моделювання професійної компетентності майбутнього вчителя музичного мистецтва буде пов'язаний з ії структурними складниками. Динамічні аспекти окресленого феномену залишаються на даному етапі поза нашої дослідницької уваги.

Звернемося до підходів відомих представників мистецької освіти щодо структури професійної компетентності майбутніх вчителів музичного мистецтва. Так Т. Пляченко, використовуючи поняття оркестрово-методична компетентність, визначає іiї як інтегративну якість майбутнього вчителя музики, котра, відображуючи його готовність і здатність професійно виконувати функції керівника учнівського музично-інструментального колективу, полягає у володінні особистісними, професійно-педагогічними й функціональними компетенціями [5].

С. Світайло базується на понятті «фахова компетентність майбутніх учителів музики», в якій виокремлює компоненти, що співвідносяться як із загальними професійно-педагогічними, так і фаховими, зокрема, диригентськохоровими діями вчителя музики, а саме:

1. Когнітивно-пізнавальний компонент, що $є$ відповідним 3 художньомистецькими компетентностями майбутніх учителів музики.

2. Ціннісно-аналітичний компонент, який $є$ суголосним 3 методичноорганізаційними компетентностями, для формування здатності оцінювати твори, здатність визначати спрямування навчально-творчої роботи на уроках музики.

3. Діяльнісно-креативний компонент, що відповідає хормейстерським компетентностям майбутніх учителів музики та передбачає діагностику музичних здібностей учнів тощо [8, с. 28-29].

Суттєвою, на нашу думку, є позиція О. Горбенко, яка загострює свою увагу на музично-виконавській компетентності як «базовій, ключовій в системі професійної підготовки вчителя музики», й інтерпретує іiі як «інтегровану професійно-значущу особистісну якість, що виявляється в здатності вчителя музики до художньої інтерпретації і творчого самовираження в різних видах музично-виконавської діяльності» [1, с. 10].

Проте, найбільш відомою й грунтовною є багатокомпонентна структура компетентностей, представлена у студіях Л. Масол, яка виділяє кілька груп компетентностей, що мають бути сформовані у процесі загальної мистецької освіти. Це такі, як-от: особистісні, функціональні, міжпредметні, соціальні [9, с. 14]. 
Відтак, беручи до уваги окреслені наукові позиції щодо структури різних компетентностей, що відбивають професійну діяльність майбутнього вчителя музичного мистецтва, відзначимо, що процес моделювання зазначеного феномену узасаднюється на структурно-діяльнісній ознаці, яка пов'язана 3 психологічною структурою діяльності, яка (за О. Леонтьєвим) визначається як єдність потреб, мети, мотивів, операцій.

У цьому контексті структура професійної компетентності майбутнього вчителя музичного мистецтва містить мотиваційно-ціннісний, когнітивний, креативно-діяльнісний компоненти. Друга позиція щодо визначення структури соціокультурних цінностей пов'язана 3 типами компетентностей майбутнього вчителя музичного мистецтва, що відбивають провідні типи професійної діяльності, а саме музично-педагогіну, диригентсько-хорову, музичновиконавську.

Перший блок моделі співпадає 3 мотиваційно-ціннісним компонентом професійної компетентності майбутнього вчителя музичного мистецтва, що містить мотиви, потреби, установки та цінності. При цьому мотив розуміємо як системне утворення особистості, що інтегрує цілі, потреби, спонукання, внутрішню позицію особистості, а цінності - як мотиваційні цілі, які служать керівними принципами в житті й провідним змістовим аспектом (за Ш. Шварцем) [11].

Отже мотиваційно-ціннісний компонент досліджуваного нами феномену пов'язаний з ціннісним ставленням до учня, з потребою у творчому спілкуванні та взаємодією з ним, з інструментальним та хоровим колективом; мотивами до музично-педагогічної, диригентсько-хорової, музично-виконавської діяльності. Тобто цей компонент пов'язаний 3 ціннісно-орієнтаційною, художньосвітоглядною, художньо-комунікативною компетентностями.

Другий блок моделі відбиває когнітивний компонент професійної компетентності й містить систему знань, які $\epsilon$ теоретичною базою професійної діяльності вчителя музичного мистецтва й трактуються нами як система понять й уявлень, що пов'язані із музично-педагогічними знаннями, а також знаннями 3 історії, теорії, методики викладання мистецтва, зокрема музичного.

До цього відносять знання щодо побудови ефективної комунікації та взаємодії з учнями у процесі виконавської, хорової та інших видів музичної діяльності; знання базових цінностей музичного мистецтва; знання про цінності майбутньої професії вчителя музики; знання щодо координації спільних дій учасників музичних колективів. Отже, цей компонент професійної компетентності пов'язаний 3 інформаційно-пізнавальною компетентністю майбутнього вчителя музичного мистецтва.

Третій блок запропонованої моделі відбиває креативно-діяльнісний компонент професійної компетентності майбутнього вчителя музичного мистецтва та пов'язаний з уміннями, творчою діяльністю та суб'єктними феноменами особистості, які дозволяють організувати іiі активність, зорієнтовану на реалізацію мотивів, цінностей, знань, здібностей щодо виконавської, хорової та інших видів діяльності. 
Цей компонент містить вміння діагностувати музичні здібності учнів, коригувати недоліки в музичному розвитку школярів, сприяти музичному формуванню особистості; культуротворчі вміння; володіння методикою музично-естетичної роботи 3 дітьми; навички гри на музичних інструментах, вміння керувати хоровим та вокальним дитячим колективом. Таким чином цей компонент професійної компетентності $\epsilon$ суголосним 3 професійнопедагогічними, функціональними, музично-виконавською компетентностями.

Обговорення. Отже маємо констатувати, що специфіка компетентнісної мистецької освіти полягає в спрямованості не на засвоєння «готових знань», що пропонуються кимось, а на дослідження «умов виникнення цього знання»; на переорієнтацію професійної освіти з «вхідних» показників (терміни, зміст, цілі навчання) на параметри «студентоиентрованої освіти», а саме: підвищення працевлаштованості випускників, формування їхньої музично-професійної культури; перехід від предметної диференціації до міждисциплінарної інтеграції тощо.

Відтак, компетентнісна орієнтація мистецької освіти означає зміну іiі результативно-цільової основи, тобто в процесі освіти майбутній фахівець музичного мистецтва повинен набути певні практико зорієнтовані знання й розвинути соціально та професійно важливі якості, володіючи якими він зможе стати успішним вчителем музичного мистецтва.

У межах реалізації компетентнісного підходу в освіті відбувається зсув акцентів у критеріях якості освіти з виконання змісту навчальних програм на оцінку міри готовності до музично-педагогіної, диригентсько-хорової, музичновиконавської діяльності.

Висновки. Ціннісні, духовні, естетичні пріоритети сучасного суспільства об'єктивно детермінують потребу сучасних мистецько зорієнтованих закладів освіти в компетентних вчителях музичного мистецтва, що актуалізує дослідження аспекту їх професійної компетентності. При цьому формування цього особистісного конструкту потребує певних результативно-цільових орієнтирів.

Вважаємо, що подана у цій статті концептуальна, прогностична, структурно-компонентна модель професійної компетентності майбутнього вчителя музичного мистецтва, що містить три блоки, які відповідно визначені як ціннісно-мотиваційний, когнітивний, креативно-діяльнісний може бути одним із варіантів розв'язання зазначеної проблеми. Проте у цій моделі зафіксовано лише структурні компоненти професійної компетентності майбутнього вчителя музичного мистецтва.

Перспективи подальших досліджень. Подальшого студіювання потребує проблема динамічних аспектів професійної компетентності майбутнього вчителя музичного мистецтва, що пов'язано з трансформацією іiі складників. 


\section{Лimepamypa}

1. Горбенко О. Критерії сформованості музично-виконавської компетентності майбутнього вчителя музичного мистецтва. Наукові записки. Вип. 87. Кіровоград: РВВ КДПУ ім. В. Винниченка, 2009. С. 56-61.

2. Зимняя Н.А. Ключевые компетентности как результативно-целевая основа компетентностного подхода в образовании. М.: ИЦ ПКПС, 2004. 220 с.

3. Моделирование психической деятельности. Ред. А.А. Братко, П.П. Волков, А.Н. Кочергин, Г.И. Царегородцев. М.: Мысль, 1969. 384 с.

4. Ожегов С.И. Толковый словарь русского языка: 80000 слов и фразеол. выражений. 4-е изд., доп. М. : ООО «А ТЕМП», 2006. 944 с.

5. Пляченко Т.М. Компетентнісна модель у структурі фахової підготовки майбутнього вчителя музики. Режим доступу: http://elibrary.kubg.edu.ua/570/1/T_Plyachenko_Kompetentnisna\%20model.pdf .

6. Пометун O. Запровадження компетентнісного підходу перспективний напрям розвитку сучасної освіти. Режим доступу: http://visnyk.iatp.org.ua

7. Савченко Р.А. Теорія і методика формування музично-педагогічної компетентності майбутніх вихователів та музичних керівників дошкільних навчальних закладів: автореф. дис ... д. пед. наук: 13.00.02. К., 2014. 43 с.

8. Світайло С.В. Формування фахової компетентності майбутніх учителів музики у процесі диригентсько-хорової підготовки: дис... канд. пед. наук :13.00.04. К., 2012. 277 с.

9. Формування базових компетентностей учнів загальноосвітньої школи у системі інтегративної мистецької освіти: посібник для вчителя. За наук. ред. Л. Масол. К.: Педагогічна думка, 2010. 232 с.

10. Штофф В. А. Моделирование и философия. Л.: Наука, 1966. 301 с.

11. Schwartz S. H. (1992). Universals in the content and structure of values: Theory and empirical tests in 20 countries. Advances in experimental social psychology. Vol. 25. 1-65.

\section{Reference}

1. Gorbenko, O. (2009). Kryterii sformovanosti muzychno-vykonavskoi kompetentnosti maibutnoho vchytelia muzychnoho mystetstva [Criteria for the formation of musical and performing competence of a future teacher of music art]. Scientific proceedings, V. Vynnychenko State Pedagogical University, 87, 56-61. (in Ukranian).

2. Zimnyaya, N. (2004). Klyuchevye kompetentnosti kak rezul'tativnocelevaya osnova kompetentnostnogo podhoda v obrazovanii [Key competencies as an effective-target basis of a competence-based approach in education]. Moscow, PC PKPS. (in Russian).

3. Bratko, A., Volko, P. \& Tsaregorodtsev, G. (1969). Modelirovanie psihicheskoj deyatel'nosti [Modelling of mental activity]. Mysl. (in Russian).

4. Ozhegov, S.I. (2006). Tolkovyj slovar' russkogo yazyka: 80000 slov $i$ frazeol. vyrazhenij [Explanatory dictionary of the Russian language: 80,000 words and 
phraseological units. expressions]. Moscow: A TEMP. (in Russian).

5. Plyachenko, T.M. Kompetentnisna model u strukturi fakhovoi pidhotovky maibutnoho vchytelia muzyky [Competence model in the structure of professional training of a future teacher of music]. Retrieved from http://elibrary.kubg.edu.ua/570/1/T_Plyachenko_Kompetentnisna\%20model.pdf. (in Ukranian).

6. Pometun, O. Zaprovadzhennia kompetentnisnoho pidkhodu perspektyvnyi napriam rozvytku suchasnoi osvity [Introduction of competence approach is a perspective direction of modern education development]. Retrieved from http://visnyk.iatp.org.ua. (in Ukranian).

7. Savchenko, R.A. (2004). Teoriia i metodyka formuvannia muzychnopedahohichnoi kompetentnosti maibutnikh vykhovateliv ta muzychnykh kerivnykiv doshkilnykh navchalnykh zakladiv: avtoref. dys ... d. ped. nauk: 13.00.02 [Theory and methods of formation of musical and pedagogical competency of future educators and music directors of preschool educational institutions: author's ref. of dissertation of a Doctor of Ped. Sciences: 13.00.02], Kyiv. (in Ukranian).

8. Svitailo, S.V. (2012). Formuvannia fakhovoi kompetentnosti maibutnikh uchyteliv muzyky u protsesi dyryhentsko-khorovoi pidhotovky: dys... kand. ped. nauk :13.00.04 [Formation of professional competence of future teachers of music in the process of conducting and choral training: dissertation of a Doctor of Ped. Science: 13.00.04]. Kyiv. (in Ukranian).

9. Masol, N., Myropolska, V. \& Ragozina, V. (2010). Formuvannia bazovykh kompetentnostei uchniv zahalnoosvitnoi shkoly u systemi intehratyvnoi mystetskoi osvity: posibnyk dlia vchytelia [Formation of basic competencies of secondary school students in the system of integrative art education: a guide for teachers]. Kyiv: Pedagogichna dumka. (in Ukranian).

10. Shtoff, V.A. (1966). Modeling and Philosophy. Science, 301. (in Russian).

11. Schwartz, S.H. (1992). Universals in the content and structure of values: Theory and empirical tests in 20 countries. Advances in experimental social psychology, 25, 1-65. 